\title{
The European Company - Will It Succeed or Will It Fail?
}

\author{
Otmar Thoemmes, Deloitte \& Touche, Munich, Germany
}

The European company, the Societas Europeae (SE) is the first pan-European legal form of company. Based on a community-wide applicable EC Regulation, the SE statute will enter into effect in all EU Member States on 8 October 2004 (the statute will also apply to the ten countries joining the EU on 1 May 2004).

The SE statute will allow companies to operate throughout the EU under a single set of rules and a unified management and reporting system, thus facilitating cross-border activities and reducing administrative and legal expenses. An SE will be able to be established as follows:

- by the merger of two or more existing public limited companies from at least two different Member States;

- by the formation of a holding company promoted by public or private limited companies from at least two different Member States;

- by the formation of a subsidiary of companies from at least two different Member States; or

- by the transformation of a public limited company which has, for at least two years, had a subsidiary in another Member State.

The ultimate success or failure of the SE, however, will depend more on its tax treatment and the attitude of the Member States in applying their tax rules to the new European entity than on the company law benefits provided by the SE statute itself.

The SE is a legal form designed for the cross-border activities of European enterprises. Article 2 of the statute requires that the founders of an SE be engaged in at least some cross-border activities in more than one EU Member State. As a result of the cross-border activity requirement, the SE will be exposed to the tax issues typical of cross-border operations to a much higher degree than ordinary companies whose activities may or may not go beyond the national boundaries of their state of incorporation. Nevertheless, the European Commission felt that the SE should not be entitled to any preferential tax treatment that is not available to other forms of companies. The Commission's concern has been that preferential tax treatment of the SE could give rise to distortions in the Common Market and result in an artificial increase in the use of the SE to the detriment of other national forms of enterprise. While this line of reasoning has some merit, it resulted in the Commission removing all tax provisions from the SE statute, so that an SE will be treated for tax purposes in the same way as any other multinational company in the relevant jurisdiction.

Unlike national companies, an SE can be created by virtue of a cross-border merger. This is a fundamental difference between national companies and the SE, because in the case of national companies, cross-border mergers inevitably require some compatibility between the tax law provisions in the Member States concerned. Logically, it would seem that enough time should have passed since the adoption of the EC Merger Directive more than 14 years ago to allow the requisite compatibility to have been achieved. And this would have been the case had all the Member States complied with the mandate of the Merger Directive to implement the tax relief for cross-border mergers into their domestic law in a timely manner. Unfortunately, to date, four Member States have yet to comply with the Merger Directive's mandate to grant relief for cross-border mergers.

The situation is exacerbated by another issue: one concerning the actual scope of the Merger Directive. A number of Member States have taken the view that the SE does not fall within the scope of the Directive because an Annex to the directive specifically enumerates the legal forms of company to which the Merger Directive applies. Naturally, the SE is not one of the companies listed in the Annex. The SE does not need to be specifically listed because Art. 10 of the SE statute stipulates that the SE must be treated by each Member State in the same way as a stock corporation. The SE statute is directly binding on Member States because it is a Council Regulation.

Nevertheless, the Commission has agreed to draft an amendment directive, which will be submitted to the Council later this year and which will specifically list the SE in the Annex to the Merger Directive. While a formal inclusion of the SE would clarify the issue provided the amendment is adopted in the near future, this course of action may ultimately confuse the issue if the amendment does not obtain the requisite unanimous consent of all Member States. Given the accession of ten new Member States on 1 May 2004, and the strict unanimity required in tax matters at the Council level, this is a likely scenario. As noted above, the Annex to the Merger Directive does not need an amendment since stock corporations are clearly covered and the SE is to be treated like a stock corporation by virtue of Art. 10 of the SE statute. Also, the inclusion of the SE into an amendment to the Merger Directive will give Member States an excuse 
for not having implemented the Merger Directive in the first instance and for not doing so in the future if the amendment fails to obtain the necessary unanimous consent. The European Commission should be aware of this risk and clarify the matter by other means, for example, by a communication to the Member States in which the Commission states its position that the SE is covered by the current version of the Merger Directive.

In addition to the possibilities for cross-border mergers, one of the novel aspects of the SE statute that will benefit cross-border activities of European groups is the ability to transfer an SE's seat. Given the advanced state of the European Internal Market and the desire of European companies to establish a head office location in accordance with business requirements, the ability to transfer its seat is a necessary feature of the SE. However, the tax treatment of the transfer of an SE's seat currently is unclear - no measure has been adopted or even drafted. In the absence of a community-wide applicable framework, the transfer of the seat of an SE may give rise to severe tax implications in the state of original incorporation. Most Member States apply liquidation treatment to the transfer of a company's seat, giving rise to full taxation of all built-in gains in the company's assets at the time of the transfer. A solution to this issue is readily available: The transfer of an SE's seat could be subject to the same type of deferral relief that the merger directive provides for cross-border mergers. An
SE transferring its seat would simply be required to leave a permanent establishment in its state of origin, to which all assets in the state of origin could be attributed for tax purposes, thus enabling that state to tax any built-in gains at the time of a (later) disposal of the assets. Member States are not prevented from applying this solution by means of unilateral tax provisions, with or without a corresponding community proposal by the Commission. In fact, one Member State, i.e. Luxembourg, has already done so and it is difficult to see why other Member States do not follow its lead.

The attitude of Member States to the tax treatment of the SE during the months until the statute enters into effect may be viewed as a kind of litmus test for their EU maturity. When deciding on the location for new investments of corporate ventures within the EU, multinational companies may regard a Member State's attitude towards the SE as an indicator of that state's general attitude towards foreign investment: Will the Member State regard foreign investment, both inbound and outbound, as a necessary means of doing business in a common European marketplace? Will it listen to business needs and invest efforts to find a mutually satisfactory solution that safeguards the fiscal interest of the Member State and the business objective of the company concerned? Or will its attitude towards the SE be governed by tax avoidance fears, prompting it to adopt restrictive and/or adverse tax measures? 